\title{
Continuity and individuality in Medieval Hereford, England: a stable isotope approach to bulk bone and incremental dentine
}

\section{Article}

Accepted Version

Creative Commons: Attribution-Noncommercial-No Derivative Works 4.0

Halldórsdóttir, H. H., Rogers, B., DiRenno, F., Müldner, G., Gröcke, D. R., Barnicle, E., Chidimuro, B., Evans, M., Morley, R., Neff, M., Sharp, C., Simpson, A., Boucher, A. and Montgomery, J. (2019) Continuity and individuality in Medieval Hereford, England: a stable isotope approach to bulk bone and incremental dentine. Journal of Archaeological Science: Reports, 23. pp. 800-809. ISSN 2352-409X doi: https://doi.org/10.1016/j.jasrep.2018.12.006 Available at https://centaur.reading.ac.uk/81494/

It is advisable to refer to the publisher's version if you intend to cite from the work. See Guidance on citing.

To link to this article DOI: http://dx.doi.org/10.1016/j.jasrep.2018.12.006

Publisher: Elsevier

All outputs in CentAUR are protected by Intellectual Property Rights law, including copyright law. Copyright and IPR is retained by the creators or other copyright holders. Terms and conditions for use of this material are defined in 
the End User Agreement.

www.reading.ac.uk/centaur

\section{CentAUR}

Central Archive at the University of Reading

Reading's research outputs online 


\title{
Continuity and Individuality in Medieval Hereford, England: a stable isotope approach to bulk bone and incremental dentine
}

\author{
Authors: \\ Hrafnhildur Helga Halldórsdóttiri, ${ }^{1,2, a, *}$, Bryony Rogers ${ }^{2 *}$, Frank A. DiRenno ${ }^{2 *}$, Gundula \\ Müldner ${ }^{3}$, Darren R. Gröcke ${ }^{4}$, Ellen Barnicle ${ }^{2}$, Blessing Chidimuro ${ }^{5}$, Malcolm Evans ${ }^{2}$, \\ Ruth Morley², Monica Neff ${ }^{2}$, Cassidy Sharp², Ashleigh Simpson², Andy Boucher ${ }^{6}$, \\ Janet Montgomery². \\ * Equal contributions \\ a Corresponding Author: h.halldorsdottir@tees.ac.uk \\ 1: School of Science, Engineering and Design, Teesside University. \\ Borough Road, Middlesbrough, TS1 3BA, United Kingdom. \\ 2: Department of Archaeology, Durham University. \\ South Rd, Durham, DH1 3LE, United Kingdom. \\ 3: Department of Archaeology, The University of Reading. \\ Whiteknights Box 227, Reading, RG6 6AB, United Kingdom. \\ 4: Department of Earth Sciences, Durham University. \\ South Rd Durham, DH1 3LE, United Kingdom. \\ 5: Department of Archaeology, University of York. \\ Wentworth Way, Heslington, York, YO10 5DD, United Kingdom. \\ 6: Headland Archaeology (UK) Ltd. \\ 13 Jane Street, Edinburgh, EH6 5HE, United Kingdom.
}




\section{Abstract}

In this study, bulk bone collagen carbon $\left(\delta^{13} \mathrm{C}\right)$ and nitrogen $\left(\delta^{15} \mathrm{~N}\right)$ isotope data from 49 individuals, recovered from two Medieval burial grounds in Hereford, England, are coupled with incremental dentine data from five individuals with high $\delta^{15} \mathrm{~N}$ bone values who survived into old age, to see whether the high $\delta^{15} \mathrm{~N}$ values were consistent throughout their childhood and adolescence. There are statistically insignificant differences between mean bone $\delta^{13} \mathrm{C}$ and $\delta^{15} \mathrm{~N}$ values from the two Hereford populations, exhumed at Cathedral Close and St. Guthlac's Priory, despite temporal and demographic differences (St Guthlac's mean: $\delta^{13} \mathrm{C}$ $19.4 \pm 0.5 \%$ and $\delta^{15} \mathrm{~N} 10.9 \pm 1.2 \%$. Hereford Cathedral mean: $\delta^{13} \mathrm{C}-19.6 \pm 0.4 \%$ ond $\delta^{15} \mathrm{~N}$ $10.4 \pm 0.9 \%$ o, $1 \sigma)$. In comparison to other contemporary urban populations, the Hereford individuals present significantly lower but more variable $\delta^{15} \mathrm{~N}$ values, suggesting a diet low in protein from high trophic level foods such as meat and milk, possibly the result of differing social status or geographic factors. The approximately 23-year long incremental dentine profiles all show considerable fluctuation in stable isotope values during childhood and adolescence for all individuals until around age 20, suggesting possible influence by physiological processes related to growth and development.

Key words:

- Carbon Stable Isotopes

- Nitrogen Stable Isotopes

- Palaeodiet

- Hereford Cathedral

- St Guthlac's Priory

- Childhood Diet 


\section{Introduction}

Coupled with archaeological, historical, and palaeopathological observations, stable isotope analysis is an increasingly valuable tool to examine palaeodietary, geographic, and temporal differences in past human populations (Lee-Thorp, 2008; Müldner and Richards, 2005, 2006, 2007a, 2007b). Typically, such analyses have been undertaken through sampling bone collagen, focusing on the ratios of carbon $\left({ }^{13} \mathrm{C} /{ }^{12} \mathrm{C}, \delta^{13} \mathrm{C}\right)$ and nitrogen $\left({ }^{15} \mathrm{~N} /{ }^{14} \mathrm{~N}, \delta^{15} \mathrm{~N}\right)$, to estimate the proportion of plant, animal, and fish protein in a population's diet, along with possible indicators of stress or illness, based on several well-established principles (Balasse and Ambrose, 2005; Beaumont and Montgomery, 2016; Cerling, 1993; Lee-Thorp, 2008). As such, the $\delta^{15} \mathrm{~N}$ values of sampled collagen will increase significantly when an individual's diet includes protein from fish, meat or animal secondary products (Schoeninger and DeNiro, 1984). These values may further be lowered by anabolic events, such as growth and pregnancy, and increased by catabolic events, such as malnutrition and illness (Fuller et al., 2004, 2005, 2006; Mekota et al., 2006; Waters-Rist and Katzenberg, 2010). Typically, $\delta^{13} \mathrm{C}$ values will predominantly reflect the photosynthetic pathway $\left(\mathrm{C}_{3}\right.$ or $\left.\mathrm{C}_{4}\right)$ of plants at the bottom of the food chain (Farquhar et al., 1989. Increased $\delta^{13} \mathrm{C}$ values can also indicate the presence of marine protein in a person's diet, due to the heightening effect of carbon reservoirs on the $\delta^{13} \mathrm{C}$ values of marine organisms, or access to imported plant protein such as millet (Schoeninger and DeNiro, 1984).

Using these principles, $\delta^{13} \mathrm{C}$ and $\delta^{15} \mathrm{~N}$ profiles for burial populations have been created to estimate the relationship between the diet, health, and socio-economic status of past populations and to provide comparisons with historical evidence (e.g. Curtis-Summers et al., 2014; Katzenberg and Lovell, 1999; Müldner and Richards, 2005, 2006, 2007a, 2007b, Thompson et al., 2008). Most commonly, these have been carried out on bone collagen, but such isotope values face the challenge that they may reflect an average of the last twenty years or more of an individual's life, depending on the rate of bone remodelling (Cox and Sealy, 1997; Hedges et al., 2007). These challenges are exacerbated by factors such as imprecise assessments of age at death, failure to resolve short-term events, and limitations in fully representative sampling, due to the inherent biases in the demography of burial populations (AlQahtani et al., 2010; Beaumont et al., 2015; Reynard and Tuross, 2015; Wood et al., 1992). However, recently refined techniques, utilising incremental primary dentine instead of bone collagen have overcome many of these issues. Primary dentine does not remodel and mineralises in a highly regular manner, recording discrete isotope values at incremental lines of growth during formation (Beaumont and Montgomery, 2015; Beaumont et al., 2013, 2014; Lee-Thorp, 2008). By sectioning primary dentine at specific intervals, isotope values can be assigned approximate known formation times and the age at which each section formed can be estimated (Beaumont and Montgomery, 2015). Using this approach, it is possible to point out specific occurrences in past individuals' lives, often related to specific events such as periods of famine (Beaumont and Montgomery, 2016), illness (Fuller et al., 2005) or weaning (Fuller et al., 2006), predominantly during childhood (cf. Beaumont and Montgomery, 2015; Beaumont et al, 2013, 2014, 2015; Eerkens et al., 2016; Montgomery et al., 2013; Sandberg et al., 2014; van der Sluis et al., 2015).

In this paper, $\delta^{13} \mathrm{C}$ and $\delta^{15} \mathrm{~N}$ profiles constructed from incrementally sampled dentine, reflecting approximately the first 23 years of life (Beaumont and Montgomery, 2015), are presented from five individuals with similar isotopic bone values. The individuals were chosen from a pool of $\delta^{13} \mathrm{C}$ and $\delta^{15} \mathrm{~N}$ bulk bone collagen data from Medieval Hereford, England, as 
they had high $\delta^{15} \mathrm{~N}$ values and all survived into adulthood. We will discuss the contribution of this incremental data to the bulk bone collagen interpretation within the context of Medieval palaeodietary research, asking whether the high $\delta^{15} \mathrm{~N}$ bulk bone values were consistent through the childhood and adolescence of the five individuals. Further, we consider any mutual characteristics present in the incremental profiles that could be attributed to underlying physiological changes during growth and development, rather than episodes of illness, famine or dietary change.

\section{The Burial Populations}

\subsection{St Guthlac's Priory}

St. Guthlac's Priory in Hereford, England, (established c. $7^{\text {th }}$ century CE) was originally located in the Castle Green area near Hereford Cathedral. Later, it was moved to its current location at the modern-day County Hospital in 1144, where it operated until 1539 (Figure 1). All mentions of St. Guthlac's Priory in this paper refer to its latter location. During excavations between 1998 and 2003, masonry associated with the priory, and a burial ground with numerous skeletal remains, were uncovered (Crooks, 2005). The burial ground at this later St. Guthlac's Priory appears to have served local parishioners (St. Peter's parish) of Hereford rather than the priory exclusively, with interments of men, women, and children, and no signs of a separate area for monks (Boucher et al., 2015; Crooks, 2005). Since the relocation of St. Guthlac's, Hereford Cathedral held a burial monopoly in Hereford, claiming all parishioners whose goods at the time of death exceeded 6 shillings, whilst women and those of lesser means were buried in their local parishes (Boucher et al., 2015, p. 11; Forrest, 2010, p. 1120). However, historical evidence indicates that in 1382, parishioners could choose where they were buried, suggesting that St. Guthlac's Priory was eventually the burial place of individuals from all socioeconomic backgrounds (Forrest, 2010, p. 1131).

Palaeopathological analysis of the burial population showed a high rate of dental caries, infection, anaemia, as well as accident- and work-related joint disease, suggesting a poor living environment, while no signs of unusual pathologies were present (Roberts, 2005; Crooks, 2005). The burial ground included at least two internment phases, the first of which appears to date to the late 12th and early 13th centuries, but the cemetery was in use until the early 16th century (Crooks, 2005).

\subsection{The Cathedral Close}

The origins of the bishopric at Hereford go back to the late $7^{\text {th }}$ century CE, with at least two Anglo-Saxon predecessor churches attested to through written documents, possibly including the former St. Guthlac's church at the Castle Green location, but archaeological evidence is scarce (Boucher et al, 2015, 1-14). The existing Cathedral dates to the first half of the $12^{\text {th }}$ century and was a popular pilgrimage site throughout the Middle Ages as the final resting place of Saint $Æ$ thelberht, an $8^{\text {th }}$ century Anglo-Saxon king and martyr, and later of Saint Thomas de Cantilupe (died 1282 CE, canonized 1320) (Boucher et al., 2015, pp. 1-14). Excavations in the modern Cathedral Close area in 1993 and 2009-11 have uncovered over 6000 individuals. Most of the burials date from after c. $1100 \mathrm{CE}$, while a large pit of disarticulated human remains were moved during the construction of the $12^{\text {th }}$ century cathedral (Boucher et al., 2015, pp. 11, 23). The site was used for burial again from the late $12^{\text {th }}$ to the 
$16^{\text {th }}$ century and three Medieval mass graves in the area have been linked to outbreaks of the Black Death in the city in 1348-49 and 1361 (Boucher, et al, 2015, 23-25). Very little is known about the Early Medieval and separate Later Medieval occupants of the mass graves. Burial rites observed for some of the Early Medieval Cathedral Close and St. Guthlac's Priory skeletons imply varied status amongst individuals from both burial grounds, with those in stone cists and coffins possibly being wealthier than those in simple shroud burials (Table 1). Due to the burial monopoly the Cathedral gained, the Early Medieval cemetery likely contains individuals from both urban and rural communities from varying levels of socioeconomic status (Boucher et al., 2015, p. 11; Forrest, 2010).

Figure 1: Map noting archaeological sites mentioned in the paper.

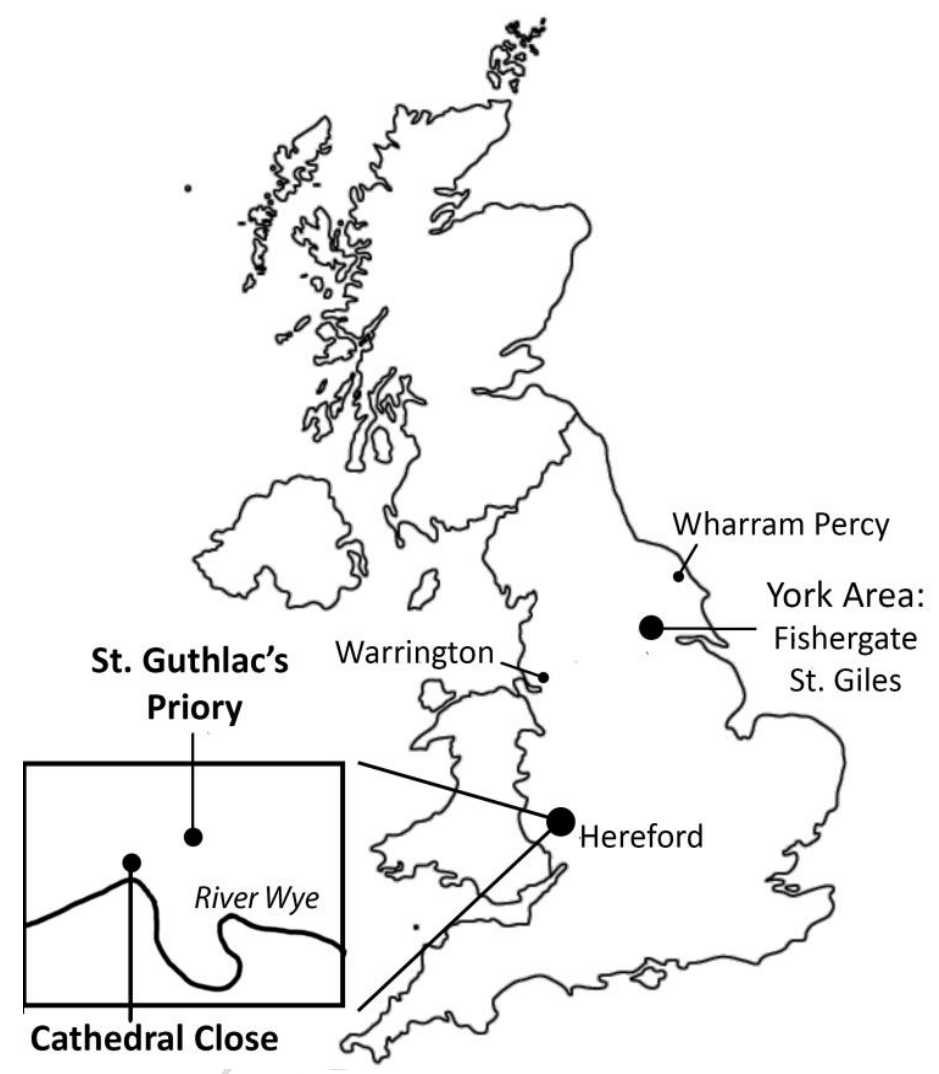

\section{Materials and Methods}

\subsection{Sample Selection}

The 20 bulk bone collagen samples from the Cathedral Close were analysed as part of the initial assessment of the 1993 excavations (Hurst et al., 2003) (Table 2). They were selected to include individuals from the main chronological phases and comprised ten samples from the Earliest Medieval burial phase, and ten from the later Medieval 'plague pits'. A further 29 individuals from the St Guthlac's Priory burial population were analysed for bulk bone collagen 
for a Medieval dietary study (Table 1). Individuals were chosen for analysis based on sample availability from the Durham University Fenwick Human Osteology Laboratory Hereford collection, and where available, cortical bone from ribs was preferred to long bones. For the incremental primary dentine study, paired mandibular left third molars (M3) and canines were taken from a sub-sample of five adult individuals based on their similarly high $\delta^{15} \mathrm{~N}$ bulk bone results (Table 1; Figure 2). This would allow for the determination of whether these high values were consistent throughout their lives.

Table 1. Tooth samples including estimated primary dentine loss through abrasion. Age categories: $O A=$ Old Adult, $M M A=$ Middle Aged Adult; $M=$ Male; F=Female.

\begin{tabular}{cccccc}
\hline \hline Skeleton ID & Sex & Age & Sample No. & Sample Type & $\begin{array}{c}\text { Estimated Dentine } \\
\text { Lost (mm) }\end{array}$ \\
\hline HERF 4001 & M & OA & 150 & $\begin{array}{c}\text { Lower Left } \\
\text { Canine } \\
\text { Lower Right M3 }\end{array}$ & 2 \\
HERF 5001 & M & MAA & 149 & $\begin{array}{c}\text { Lower Left } \\
\text { Canine } \\
\text { Lower Left M3 }\end{array}$ & 0 \\
HERF 9515 & M & OA & 147 & $\begin{array}{c}\text { Lower Left } \\
\text { Canine } \\
\text { Lower Left M3 }\end{array}$ & 2 \\
HERF 9526 & M? & OA & 142 & $\begin{array}{c}\text { Lower Left } \\
\text { Canine } \\
\text { Lower Left M3 }\end{array}$ & 2 \\
\hline HERF 9543 & F & OA & 141 & $\begin{array}{c}\text { Lower Left } \\
\text { Canine }\end{array}$ & 0 \\
\hline \hline
\end{tabular}

\subsection{Sample Preparation and Stable Isotope Analysis}

The bone samples from Hereford Cathedral Close were analysed in 2002 in the Department of Archaeological Sciences, University of Bradford, using the modified Longin method with ultrafiltration following Brown et al. (1988), as described in Müldner and Richards (2005).

For the St. Guthlac's Priory samples, 100-200 mg sections were cut from bone elements, while teeth were bisected and enamel removed from one half of the tooth following method 2 outlined by Beaumont et al. (2013). Secondary dentine was also removed by abrading the pulp chamber (Beaumont et al., 2015). Tooth and bone elements were demineralised in $0.5 \mathrm{M} \mathrm{HCl}$ at $4^{\circ} \mathrm{C}$. Once demineralised, teeth were cut into horizontal sections (c.1 $\mathrm{mm}$ ) from crown to root apex and each section placed into a separately labelled micro tube. Collagen was extracted following the original Longin method (1971) and gelatinised bone collagen was Ezee filtered. Dentine filtration was considered unnecessary due to the lack of exogenous debris compared to bone (Beaumont et al., 2014). Samples were frozen, then freeze-dried at $-30^{\circ} \mathrm{C}$ and $300 \mathrm{mmHg}$ for 48 hours. The resulting collagen was weighed to calculate the minimum collagen yield. All tools and surfaces were thoroughly cleaned between samples to avoid cross-contamination. 
Aliquots of $0.3-0.4 \mathrm{mg}$ of collagen were weighed out into $4 \times 6 \mathrm{~mm}$ tin foil cylinders. Total organic carbon, total nitrogen content, and stable isotope ratios were calculated using a Costech Elemental Analyser (ECS 4010) connected to a ThermoFinnigan Delta V Advantage isotope ratio mass spectrometer in the Durham University Stable Isotope Biochemistry Lab (SIBL), Department of Earth Sciences. Isotopic accuracy was monitored through routine analyses of in-house standards, calibrated against international standards (e.g., USGS 40, USGS 24, IAEA 600, IAEA N1, IAEA N2) with a linear $\delta^{13} \mathrm{C}$ range between $-46 \%$ and $+3 \%$ and $\delta^{15} \mathrm{~N}$ range between $-4.5 \%$ and $+20.4 \%$. Analytical uncertainty in carbon and nitrogen isotope analysis was typically $0.1 \%$ for replicate analyses of the international standards and $<0.2 \%$ on replicate sample analysis. Total organic carbon and nitrogen data was obtained as part of the isotope analysis using an internal standard (Glutamic Acid, $40.82 \%$ C, $9.52 \% \mathrm{~N}$ ) and C: $\mathrm{N}$ ratios were recorded to examine diagenetic effects (Ambrose, 1990). Carbon isotope ratios were corrected for ${ }^{17} \mathrm{O}$ contribution, and isotope ratios were expressed as parts per thousand (\%o) relative to Vienna Pee Dee Belemnite (VPDB) for carbon, and Ambient Inhale Reservoir (AIR) for nitrogen (Werner and Brand, 2001) as:

$$
\begin{aligned}
& \text { Equation } 1 \\
& \delta \% o=\left(R_{\text {Sample }} / R_{\text {Standard }}-1\right) * 1000
\end{aligned}
$$

\subsection{Data Analysis}

Analytic uncertainty of standards appears at 2 s.d. on all graphs $( \pm 0.4 \%)$. All bone samples were measured in duplicate and mean values calculated. Most of the dentine samples used to construct dietary profiles were analysed as single samples with selected increments measured in duplicate for quality control. Bulk bone data was plotted on scatter charts, summary statistics calculated and non-parametric statistical tests carried out for comparative statistics using IBM SPSS 24. Non-parametric tests were chosen due to the small and varying sample sizes of compared variables, and presence of outliers in the data.

Age ranges were assigned to individual dentine sections by dividing the total time of tooth formation, using a modified version of the equation outlined by Beaumont and Montgomery (2015) (Equation 2), and located on the approximate midpoints of each individual dentine section range on graphs (Equation 3).

$$
\begin{gathered}
\text { Equation } 2 \\
\text { Section Formation Time (years) }=\frac{\text { Total tooth formation time }(\text { years })}{\text { Number of sections }-1} \\
\text { Equation } 3 \\
2
\end{gathered}
$$

Some teeth were visibly worn through the occlusal enamel into the primary dentine. In worn canines, the expected weaning signal was also missing from isotope profiles. To combat offsets in age caused by this loss, the amount of dentine lost at the occlusal end of the sequence was estimated in millimetres (Table 1). As each increment is $1 \mathrm{~mm}$ in width, this 
number of increments is equivalent to the number of estimated millimetres lost. This number was then added to the total number of cut increments for each worn tooth in Equation 2, to calculate a more accurate formation time per section. The missing sections were also accounted for when assigning ages to each incremental section, with worn teeth starting at later ages than unworn teeth (See Supplementary Information 1).

\section{Results and Discussion}

With one exception from Cathedral Close (HFD-4241), all bone and dentine samples met the standards for collagen quality and yield. C:N ratios were within the accepted range of 2.9-3.6 (DeNiro, 1985) and each sample had a collagen yield above 1\% (van Klinken, 1999).

Table 2: Results of carbon and nitrogen isotope analysis of the rib and cortical bone samples from Hereford. Age categories: $O A=$ Old Adult, $Y M A=$ Young Middle-Aged Adult, MAA = Middle Aged Adult, OMA = Old Middle-Aged Adult, $A=$ Adult, $Y A=$ Young Adult. Site Categories: SGP.LM = St. Guthlac's Priory, Late Medieval, CC.LM = Cathedral Close, Late Medieval (mass graves), CC.EM = Cathedral Close, Early Medieval; $M=$ Male; F=Female. Notes include observations on location and pathologies, signs of coffins, cists or grave position and sample type.

\begin{tabular}{|c|c|c|c|c|c|c|}
\hline Skeleton ID & Site & Sex & Age & Notes and sample type & $\begin{array}{l}\delta^{13} \mathrm{C} \\
(\% \circ)\end{array}$ & $\begin{array}{l}\delta^{15} \mathrm{~N} \\
(\% 0)\end{array}$ \\
\hline HERF 1301 & SGP.LM & $\mathrm{F}$ & YA & $\begin{array}{l}\text { S end piles. Dental pathology } \\
\text { and trauma. Does not fit } \\
\text { grave. Rib. }\end{array}$ & -19.3 & 11.2 \\
\hline HERF 1303 & SGP.LM & $\mathrm{F}$ & MAA & $\begin{array}{c}\text { pathology. Arms crossed. } \\
\text { Rib. }\end{array}$ & -19.3 & 10.9 \\
\hline HERF 1801 & SGP.LM & $?$ & $8-10 y r$ & $\begin{array}{c}\text { S end (west) piles. Askew in } \\
\text { grave. Rib. }\end{array}$ & -19.3 & 8.3 \\
\hline HERF 2301 & SGP.LM & $?$ & $8-10 y r$ & $\begin{array}{l}\text { S End piles. Rib. } \\
\text { S end piles. Dental }\end{array}$ & -19.4 & 12.0 \\
\hline HERF 2302 & SGP.LM & M & YA & $\begin{array}{c}\text { pathology. Praying position. } \\
\text { Rib. }\end{array}$ & -19.3 & 9.6 \\
\hline HERF 2320 & SGP.LM & $\mathrm{F}$ & OA & $\begin{array}{l}\text { S end piles. Infection. Does } \\
\text { not fit grave. Rib. }\end{array}$ & -19.3 & 11.2 \\
\hline HERF 4001 & SGP.LM & $M$ & YA & $\begin{array}{l}\text { S end drain run. Pathologies. } \\
\text { Rib. }\end{array}$ & -19.3 & 11.4 \\
\hline HERF 5001 & SGP.LM & $M$ & MAA & $\begin{array}{l}\text { S end footing. Possible } \\
\text { coffin. Anaemic. Rib. }\end{array}$ & -19.3 & 11.9 \\
\hline HERF 6001 & SGP.LM & $M$ & OA & $\begin{array}{l}\text { S end footing. Coffin nail } \\
\text { found. Rib. }\end{array}$ & -19.9 & 10.7 \\
\hline HERF 7001 & SGP.LM & M & $A$ & S end Later phase. Rib. & -19.8 & 11.2 \\
\hline HERF 7002 & SGP.LM & M & $A$ & S end Early phase. Femur. & -19.1 & 10.3 \\
\hline HERF 7003 & SGP.LM & $\mathrm{F}$ & YA & S end Early phase. Rib. & -19.2 & 10.6 \\
\hline HERF 8101 & SGP.LM & $?$ & $3-6 y r$ & $\begin{array}{c}\mathrm{N} \text { west. Possible coffin. } \\
\text { Earlier burial. Rib. }\end{array}$ & -19.6 & 9.2 \\
\hline HERF 8112 & SGP.LM & M & A & $\begin{array}{c}\text { N west. Grave aligned NS. } \\
\text { Early grave. Rib. }\end{array}$ & -20.4 & 10.7 \\
\hline
\end{tabular}




\begin{tabular}{|c|c|c|c|c|c|c|}
\hline HERF 8113 & SGP.LM & $? \mathrm{M}$ & $A$ & $\begin{array}{l}\mathrm{N} \text { West. Fragmentary } \\
\text { remains. Cortical bone. }\end{array}$ & -18.8 & 11.0 \\
\hline HERF 8114 & SGP.LM & $\mathrm{F}$ & YA & $\begin{array}{l}\text { N West. Infection. Tooth } \\
\text { decay. Cortical bone. }\end{array}$ & -19.3 & 9.0 \\
\hline HERF 8115 & SGP.LM & $?$ & $6-8 y r$ & N West. Anaemia. Rib. & -19.4 & 11.5 \\
\hline HERF 8301 & SGP.LM & M & $A$ & $\begin{array}{l}\text { N Central. Infection. Legs in } \\
\text { bent position. Femur. }\end{array}$ & -19.5 & 10.3 \\
\hline HERF 8307 & SGP.LM & $? \mathrm{~F}$ & YA & N Central. Cist. Rib. & -20.1 & 10.1 \\
\hline HERF 8308 & SGP.LM & $?$ & $A$ & $\begin{array}{c}\text { N Central. Coffin. Infection. } \\
\text { Tibia. }\end{array}$ & -19.4 & 9.8 \\
\hline HERF 8501 & SGP.LM & $\mathrm{F}$ & YA & Rib. & -20.1 & 8.9 \\
\hline HERF 9501 & SGP.LM & M & YA & $\begin{array}{l}\text { N Central/Road. Coffin. } \\
\text { Anaemia. Rib. }\end{array}$ & -19.0 & 13.3 \\
\hline HERF 9502 & SGP.LM & $?$ & $?$ & $\begin{array}{l}\text { N Road. Phase 3. Coffin. } \\
\text { Cortical bone. }\end{array}$ & -18.5 & 12.7 \\
\hline HERF 9510 & SGP.LM & $\mathrm{F}$ & YA & $\begin{array}{l}\text { N Road. Cist. Pathologies. } \\
\text { Rib. }\end{array}$ & -19.1 & 11.5 \\
\hline HERF 9515 & SGP.LM & M & OA & $\begin{array}{l}\text { N Road. Coffin. Chalice in } \\
\text { grave. Rib. }\end{array}$ & -19.3 & 11.1 \\
\hline HERF 9526 & SGP.LM & M & OA & $\begin{array}{l}\text { N Road. Large Coffin. } \\
\text { Praying position. Rib. }\end{array}$ & -18.1 & 13.1 \\
\hline HERF 9529 & SGP.LM & M & YA & $\begin{array}{l}\text { N Road. Phase 3. Pathology. } \\
\text { Rib. }\end{array}$ & -19.9 & 12.6 \\
\hline HERF 9534 & SGP.LM & $?$ & $12-13 y r$ & N road. Phase 2. Coffin. Rib. & -19.3 & 11.2 \\
\hline HERF 9543 & SGP.LM & $\mathrm{F}$ & $\mathrm{OA}$ & $\begin{array}{c}\text { N road. Phase 2. No nails. } \\
\text { Rib. }\end{array}$ & -19.5 & 12.0 \\
\hline HFD 739 & CC.LM & $\mathrm{F}$ & OMA & Rib. & -19.7 & 11.1 \\
\hline HFD 1650 & CC.LM & M & YA & Rib. & -19.7 & 10.8 \\
\hline HFD 1886 & CC.LM & $\mathrm{F}$ & OMA & Rib. & -20.2 & 8.9 \\
\hline HFD 2054 & CC.LM & M & OMA & Rib. & -19.2 & 11.1 \\
\hline HFD 2599 & CC.LM & M & OMA & Rib. & -19.3 & 10.0 \\
\hline HFD 2749 & CC.LM & $F$ & $\mathrm{OA}$ & Rib. & -19.4 & 10.3 \\
\hline HFD 2831 & CC.LM & M & OMA & Rib. & -20.3 & 8.5 \\
\hline HFD 2862 & CC.LM & $M$ & OMA & Rib. & -18.8 & 12.0 \\
\hline HFD 3152 & CC.LM & $\mathrm{F}$ & YMA & Rib. & -19.4 & 10.5 \\
\hline HFD 3221 & CC.LM & $\mathrm{F}$ & YMA & Rib. & -19.7 & 10.7 \\
\hline HFD 3732 & CC.EM & $\mathrm{F}$ & OA & Rib. & -20.1 & 10.6 \\
\hline HFD 3734 & CC.EM & M & $\mathrm{OA}$ & Rib. & -19.7 & 10.7 \\
\hline HFD 3917 & CC.EM & M & OMA & Rib. & -19.3 & 11.9 \\
\hline HFD 4093 & CC.EM & $\mathrm{F}$ & OMA & Rib. & -19.7 & 10.0 \\
\hline HFD 4116 & CC.EM & $\mathrm{F}$ & OA & Rib. & -19.5 & 10.7 \\
\hline HFD 4145 & CC.EM & $\mathrm{F}$ & OMA & Face down (reburial). Rib. & -19.6 & 9.8 \\
\hline HFD 4191 & CC.EM & $M$ & YMA & Rib & -19.3 & 10.8 \\
\hline HFD 4243 & CC.EM & $? \mathrm{~F}$ & OA & Rib & -19.8 & 9.3 \\
\hline HFD 4375 & CC.EM & $? \mathrm{M}$ & $A$ & Rib & -19.7 & 10.0 \\
\hline
\end{tabular}




\subsection{Bone Collagen and the Burial Populations}

Complete bone collagen results for the burial population at St. Guthlac's priory and Hereford Cathedral Close are presented in Table 2 and Figure 2. At St. Guthlac's Priory, $\delta^{13} \mathrm{C}$ values ranged from $-20.4 \%$ to $-18.1 \%$, with a mean value of $-19.4 \pm 0.5 \%$ at 1 s.d., and $\delta^{15} \mathrm{~N}$ values from $8.3 \%$ to $13.3 \%$, with a mean value of $10.9 \pm 1.2 \%$ at 1 s.d. At the Cathedral Close, $\delta^{13} \mathrm{C}$ values are very similar, with a mean value of $-19.6 \pm 0.4 \%$ at 1 s.d. and ranging between $20.3 \%$ and $-18.8 \%$. Individuals from the Cathedral Close also have $\delta^{15} \mathrm{~N}$ values that are very similar to those from St Guthlac's Priory, ranging from $8.5 \%$ o to $12 \%$ with a mean of 10.4 $\pm 0.9 \%$ at 1 s.d.

Figure 2: Bulk bone stable isotope values from all Hereford populations. Individuals whose incremental dentine values were analysed are shaded. Analytical error in top left corner at 2 s.d.

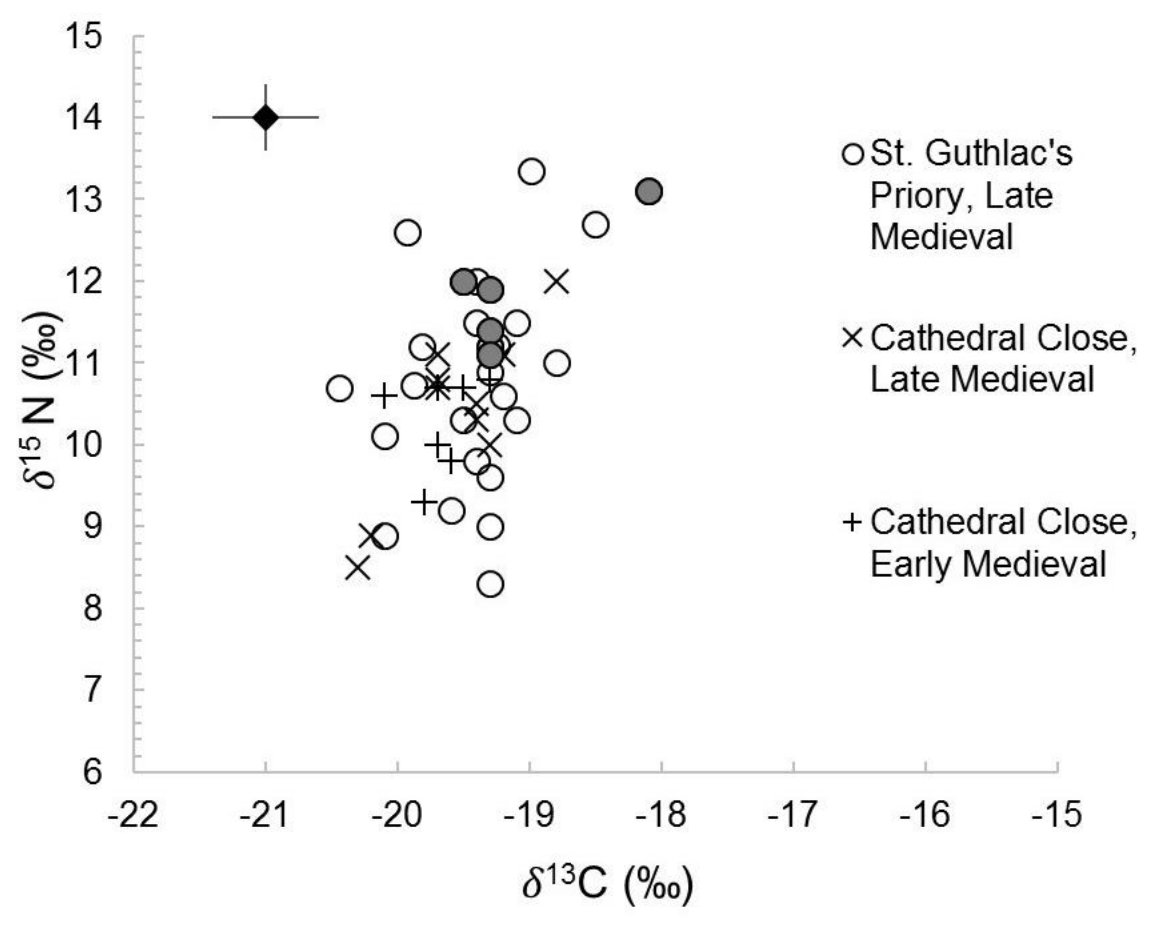

A Kruskal-Wallis $\mathrm{H}$ test indicates that the overall differences in the $\delta^{13} \mathrm{C}$ and $\delta^{15} \mathrm{~N}$ values from the three different burial contexts are statistically insignificant (Table 3 ), indicating a demographic similarity between the two burial grounds and continuity in diet and health in Hereford throughout the Medieval Period. Despite these similarities, the stable isotope data does portray variability between the individuals within each population. While adults and males appear to have higher mean $\delta^{15} \mathrm{~N}$ and $\delta^{13} \mathrm{C}$ values than females and children (Table 4), a Mann-Whitney test indicates differences between the two are statistically insignificant (Table 3). Therefore, this variability does not appear to be heavily affected by biological sex or age. Intra-population variability in burial populations at Medieval English sites in Yorkshire and Cheshire (Figure 3) has been attributed to differences in social position. For example, fish and meat was limited to the more affluent due to their higher price compared to that of grain and vegetables (Müldner and Richards, 2005, 2007a, 2007b; Richards et al., 2002; Woolgar et al., 2006, pp.191-198). At St. Guthlac's Priory, the three individuals with the highest $\delta^{15} \mathrm{~N}$ values (HERF 9501, 9502, 9526) were buried in coffins, while the individuals with the lowest $\delta^{15} \mathrm{~N}$ 
values (HERF 1801, 8114, 8501) were not. As the presence of coffins has been associated with higher status, this indicates that, similarly to the Cheshire and Yorkshire populations, status influenced the intrapopulation variability at St. Guthlac's Priory.

Table 3: Kruskal-Wallis $H$ test results, with significance level ( $\alpha$ ) at 0.05 for the null-hypothesis that samples represent statistics from identical populations, with chance variation, using IBM SPSS (24.0). No significant difference detected between any samples. SGP.LM = St. Guthlac's Priory, Late Medieval, CC.LM = Cathedral Close, Late Medieval (mass graves), CC.EM = Cathedral Close, Early Medieval; $Y A=$ Young Adult; $A=$ Adult; $M A A=$ Middle Aged Adult; YMA = Young Middle-Aged Adult; OMA = Old Middle-Aged Adult; OA = Old Adult.

\begin{tabular}{ccc}
\hline \hline & $\delta^{15} \mathrm{~N}(\%)$ & $\delta^{13} \mathrm{C}(\%)$ \\
\hline Samples & $\mathrm{p}$-value \\
\hline $\begin{array}{c}\text { SGP.LM, CC.LM and CC.EM } \\
\text { Males/probable males and females/probable } \\
\text { females }\end{array}$ & 0.167 & 0.102 \\
$\begin{array}{c}\text { Children/non-adults/YA and } \\
\text { A/MAA/YMA/OMA/OA }\end{array}$ & 0.089 & 0.088 \\
\hline \hline
\end{tabular}

Figure 3: $\delta^{13} \mathrm{C}$ and $\delta^{15} \mathrm{~N}$ values of Hereford bulk bone results compared to mean and $1 \mathrm{s.d}$. values of assemblages from York and Wharram Percy, Yorkshire and Warrington, Cheshire (Müldner and Richards, 2005, 2007a, 2007b; Richards et al., 2002). Analytical error in top left corner at 2 s.d.

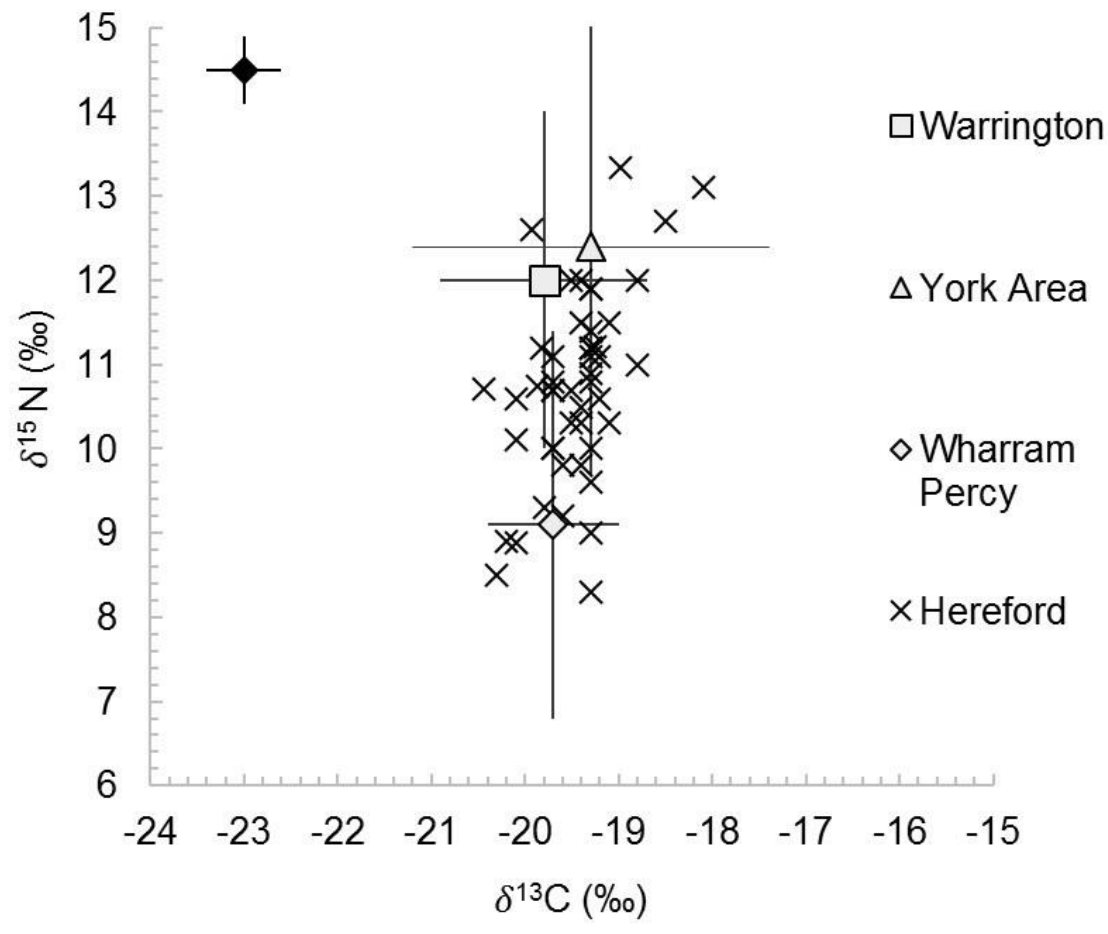


Table 4: Summary statistics of specific demographics in Hereford populations. SGP.LM = St. Guthlac's Priory, Late Medieval, CC.LM = Cathedral Close, Late Medieval (mass graves), CC.EM = Cathedral Close, Early Medieval; YA = Young Adult; YMA = Young Middle-Aged Adult; $A=$ Adult; $M A A=$ Middle Aged Adult; OMA = Old Middle Aged Adult; OA = Old Adult; $M=$ Male; F=Female.

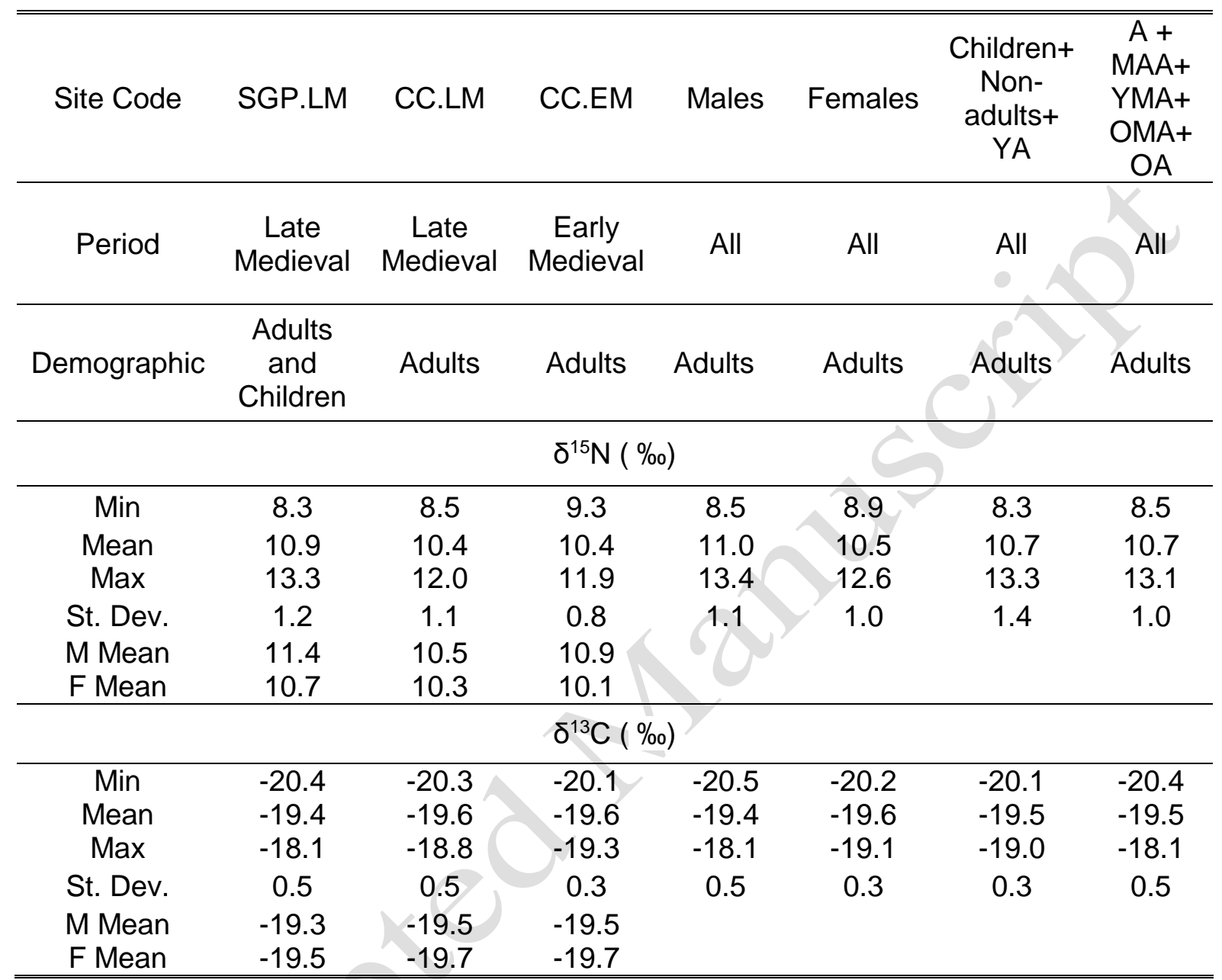

In the Yorkshire and Cheshire burial assemblages, variation in the $\delta^{13} \mathrm{C}$ and $\delta^{15} \mathrm{~N}$ values between populations was largely attributed to differences between urban and rural environments, especially considering proximity to urban fishing rivers and trading centres (Müldner and Richards, 2005, 2007a, 2007b; Richards et al., 2002). In agreement with this, the similarity between the two Hereford burial populations is not surprising, as both are associated with city parishes drawing from geographically similar populations. Both Hereford sites are similar to the Yorkshire and Cheshire populations with regard to $\delta^{13} \mathrm{C}$ values, indicating a largely terrestrial diet. In contrast, mean $\delta^{15} \mathrm{~N}$ values in Hereford are considerably lower than those of the Yorkshire and Cheshire populations, with the exception of rural Wharram Percy, which had similarly low mean $\delta^{15} \mathrm{~N}$ values (Figure 3; Table 5). This is somewhat surprising, as St. Guthlac's Priory and the Cathedral Close are both located within a trading centre (Hereford) and in proximity with the River Wye, which $18^{\text {th }}$ century texts claim produced 'extremely cheap' fish, especially salmon, in Medieval times (Price, 1796, p. 66). No $\delta^{13} \mathrm{C}$ and $\delta^{15} \mathrm{~N}$ values are available for faunal bone or botanical remains in Herefordshire, so factors unique to the geographic area of Hereford cannot be accounted for. For example, $\delta^{15} \mathrm{~N}$ values for fish can vary considerably between different species and river systems (Dempson 
et al., 2009), and the effects of possible region-specific crop manuring practices that can affect the amount of nitrogen cycling in the food web cannot be taken into account (Bogaard et al., 2007). Although the burial populations at St. Guthlac's Priory and the Cathedral Close may appear to have subsisted on a more plant-based diet than the comparative urban populations in Yorkshire and Cheshire, it is impossible to attempt such comparisons without geographic baseline data. Intra-population variability may, however, be examined more closely by using incremental dentine analysis.

Table 5: Contextual information and summary statistics of stable isotopic values for Late Medieval English burial populations. Citations: 1) Müldner and Richards, 2005 2) Müldner and Richards, 2007b 3) Richards et al., 2002.

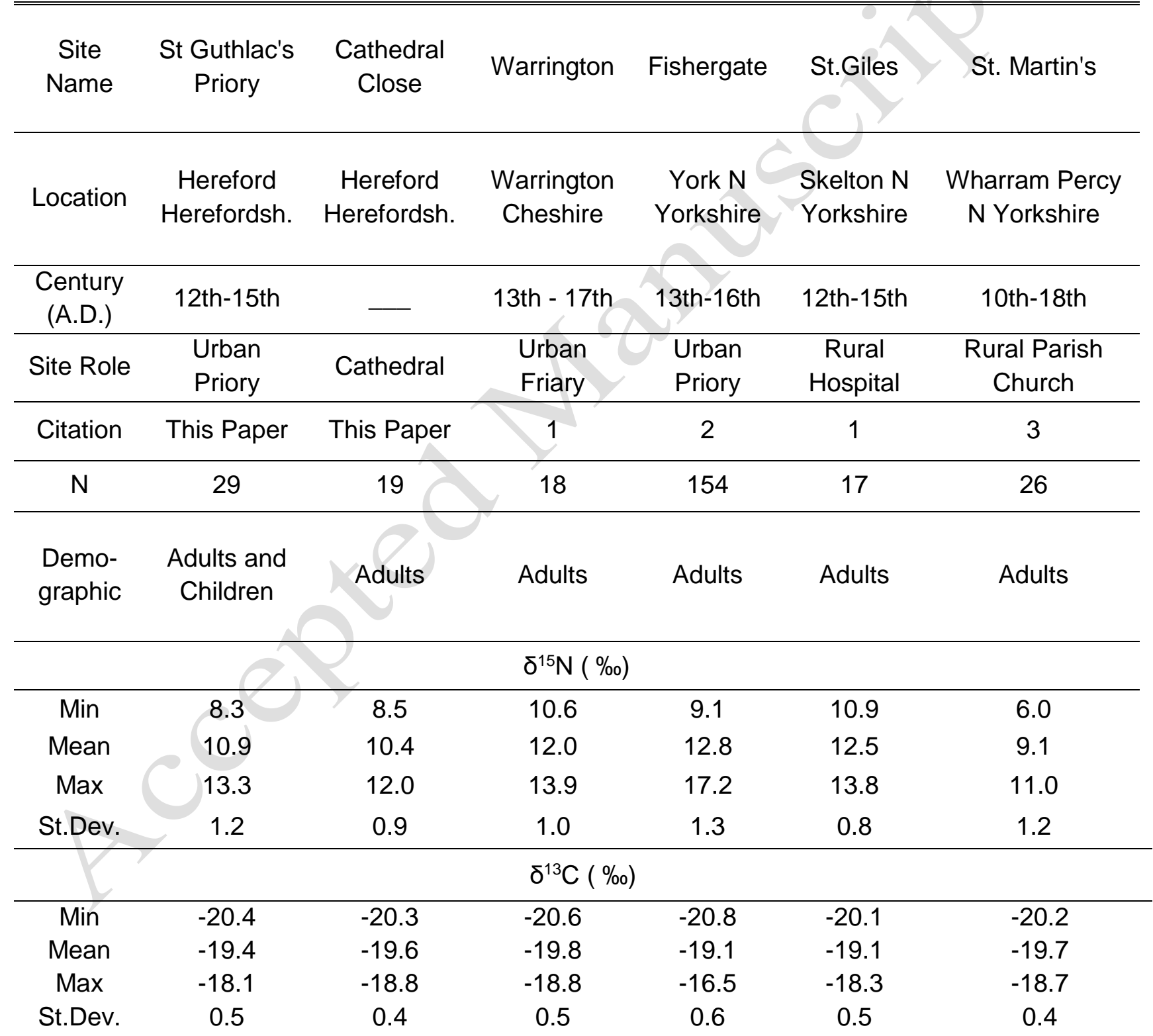




\subsection{Dentine Collagen and the Early Life Histories of Five Individuals at St. Guthlac's Priory}

The $\delta^{13} \mathrm{C}$ values of all individuals sampled for their incremental dentine ranged from $-22.0 \%$ to $-16.8 \%$ and $\delta^{15} \mathrm{~N}$ values from $8.0 \%$ to $14.6 \%$, presenting greater variability in total than was found in the bone collagen (Figures 4 and 5; Supplementary Information 1). The individuals' combined dentine profiles have a mean range of $2.0 \%$ in $\delta^{13} \mathrm{C}$ values and $3.4 \%$ in $\delta^{15} \mathrm{~N}$, despite all five individuals having similar bone collagen isotope values. Individuals without extensive occlusal tooth wear (5001, 9515 and 9543) have high $\delta^{15} \mathrm{~N}$ values initially, which drop $\sim 2 \%$ by two years of age, strongly indicative of weaning. Similar patterns have been observed in populations ranging from the Medieval period to modern times, and are typically ascribed to weaning (Richards et al., 2002; Fuller et al., 2006; Burt, 2015; van der Sluis et al., 2015). However, the $\delta^{13} \mathrm{C}$ profiles of the St. Guthlac's Priory individuals do not show the same expected drop with the lowered trophic level. This may be caused by the averaging effects of dentine formation, as studies of modern infants indicate that the $\delta^{13} \mathrm{C}$ drop is more rapid than that of $\delta^{15} \mathrm{~N}$ (Fuller et al., 2006). It may also be related to other less-known physiological factors or the mother's diet and health (Beaumont et al., 2015). Alternatively, the expected carbon shift to lower values could be compensated for by a change to a diet with a lower lipid content and hence higher $\delta^{13} \mathrm{C}$, although to date this has mainly been observed in modern biological studies (McCutchan et al., 2003; Stott et al., 1999).

Unique differences between the individuals analysed also highlight the way each person's individuality and different life experiences need to be considered when attempting to identify cultural trends in bone data. For example, individual 9543, who was buried in a coffin, appears to have had higher $\delta^{15} \mathrm{~N}$ values than the others until her early $20 \mathrm{~s}$. Her terrestrial $\delta^{13} \mathrm{C}$ values during this period of elevated $\delta^{15} \mathrm{~N}$ suggest freshwater fish or terrestrial meat consumption rather than significant marine protein consumption. She was the only female included in the incremental analysis, and females have been reported to exhibit higher $\delta^{15} \mathrm{~N}$ values during childhood than males due to unknown cultural or physiological factors (Henderson et al., 2014). Whilst she is the only female included in this analysis, making it difficult to say whether this is a factor in her case, coffins were mainly afforded to higher status individuals at St. Guthlac's, which suggests socioeconomic status may be the explanation for the high $\delta^{15} \mathrm{~N}$ values observed in her case. Another individual, 9526, has the largest range of $\delta^{15} \mathrm{~N}$ values (10.4-14.0\%) among the group, manifesting a similar pattern during childhood as individual 9543. This individual also had the highest $\delta^{13} \mathrm{C}$ and $\delta^{15} \mathrm{~N}$ bone values of all analysed Hereford individuals and evidence of a large burial coffin suggests the individual may have been obese (Crooks, 2005). Excluding adolescence, this individual appears to have maintained these high $\delta^{15} \mathrm{~N}$ values from his early twenties, with $\delta^{13} \mathrm{C}$ values rising steadily throughout his earlier life, which may indicate increasing access to marine foods. In conjunction with his possible obesity, this could indicate that this was an individual of relatively high socio-economic status due to increased access to food resources compared to the rest of the population.

The remaining individuals $(4001,5001,9515)$ are similar to each other, exhibiting relatively low $\delta^{13} \mathrm{C}$ and $\delta^{15} \mathrm{~N}$ dentine values between the ages of 8 and 17 compared to the population's mean adult bone collagen values, and $\delta^{15} \mathrm{~N}$ values that rise slightly above the population mean after age 18. Interestingly, 5001 and 4001 were excavated from the southern part of the burial ground and exhibited various pathologies, such as cribra orbitalia (Roberts, 2005). Although individual 9515 did have relatively high $\delta^{15} \mathrm{~N}$ values around age 6 to 8 , prior to this his profile fluctuates below the population mean. Due to the presence of a mortuary 
chalice in his grave, it has been suggested that he may have been a priest, or at least associated with the clergy (Crooks, 2005). However, his relatively low values contrast with several other 'priest' burials from other contemporary populations, where both $\delta^{13} \mathrm{C}$ and $\delta^{15} \mathrm{~N}$ values were higher than those of the general population (Müldner and Richards, 2005, 2007b; Patrick, 2014). Conversely, another possible priest from St. Giles, Yorkshire, expressed isotopic ratios similar to his population's mean (Müldner and Richards, 2005), implying that the possible priests at St. Guthlac's and St. Giles may have had diets comparable to those of the lay population.

Figure 4: Incremental dentine stable isotope values inferred to individual approximate age in years. Each graph depicts one individual, with $\delta^{15} \mathrm{~N}$ values above with left axis values, and $\delta^{13} \mathrm{C}$ values below with right axis values. Canine values are filled, while $\mathrm{m} 3$ values are not. $X$ axis represents approximate age in years as calculated using equations 2 and 3 . Analytical errors in top left corner at 2 s.d.
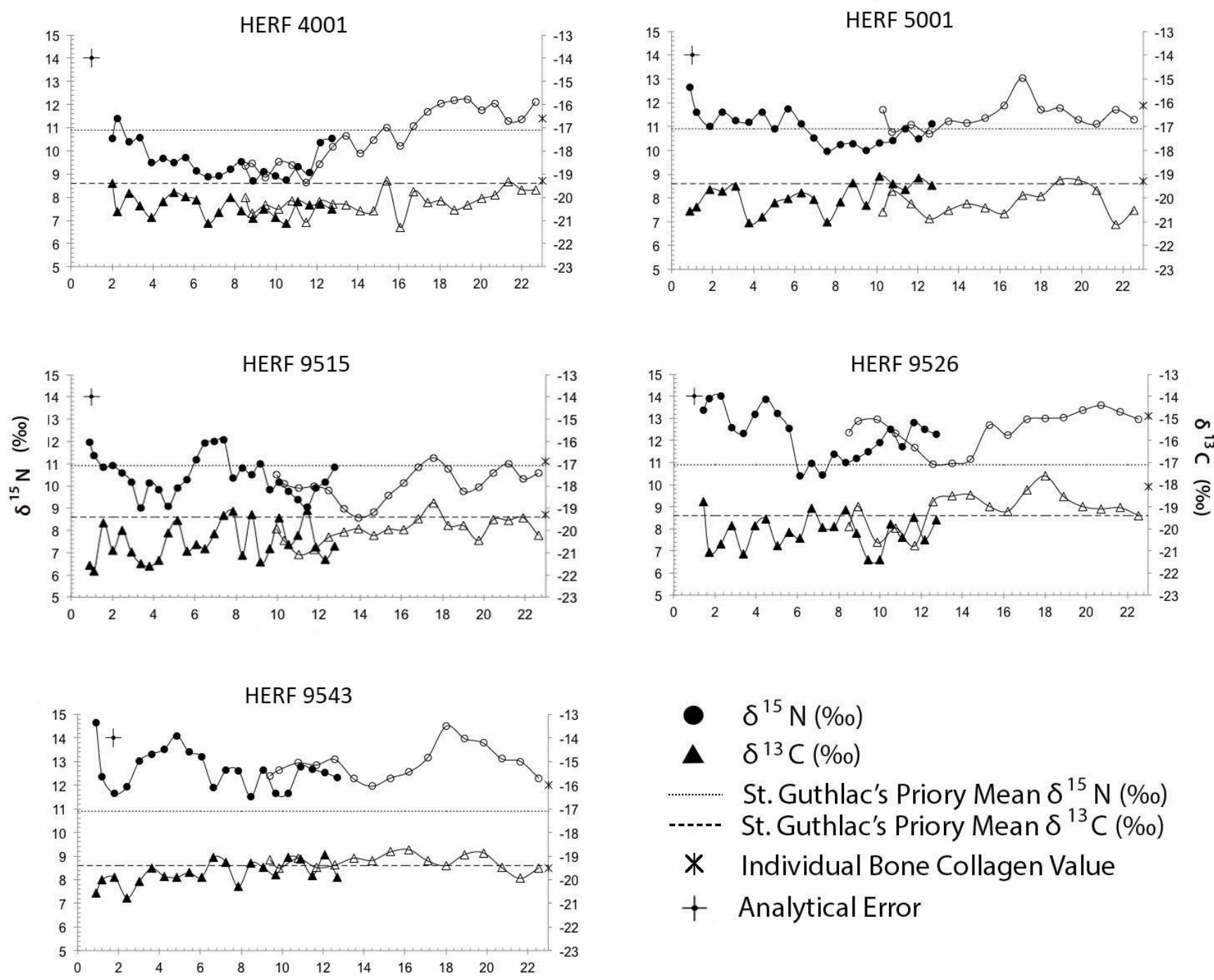

$$
\begin{aligned}
& \text { - } \delta^{15} \mathrm{~N}(\% \mathrm{o}) \\
& \text { - } \delta^{13} \mathrm{C}(\% \mathrm{o}) \\
& \text { St. Guthlac's Priory Mean } \delta^{15} \mathrm{~N}(\% \mathrm{o}) \\
& \hdashline-.- \text { St. Guthlac's Priory Mean } \delta^{13} \mathrm{C}(\% \mathrm{o}) \\
& * \quad \text { Individual Bone Collagen Value } \\
&+\quad \text { Analytical Error }
\end{aligned}
$$


It is notable that the lowest $\delta{ }^{15} \mathrm{~N}$ values are generally present between the ages of 8 and 16 (Figure 4, 5a-b). This may be caused by one of two things: a specific adolescent diet prior to transitioning to an adult diet with higher levels of animal protein, as suggested at Wharram Percy (Richards et al., 2002) and Çatalhöyük, Turkey (Pearson et al., 2015), or changes in nitrogen fractionation associated with growth and development (Henderson et al., 2014; Waters-Rist and Katzenberg, 2010). Similar patterns have been observed in several other burial populations, with connections being drawn between the main growth period of humans and reduced $\delta^{15} \mathrm{~N}$ values between the ages of 10 and 18 (cf. Eerkens et al., 2016; Reitsema, 2013; van der Sluis et al., 2015; Waters-Rist and Katzenberg 2010). Fuller et al. (2004) have also observed lower $\delta^{15} \mathrm{~N}$ values associated with increased BMI during pregnancy using hair, and a similar growth-related relationship has been reported in various animal species soft tissue, such as fish, birds and foxes (Minagawa and Wada, 1984; Roth and Hobson, 2000; Trueman et al., 2005). Further, the dentine profile of a Neolithic individual from Sumburgh in Shetland (Montgomery et al., 2013) and an alternate primate species, the Rhesus monkey (Reitsema and Muir, 2015) bore lower $\delta^{15} \mathrm{~N}$ values during adolescence than adulthood. Although distinct species at different periods of time may undergo different fractionation processes, the pan-occurrence of this phenomenon within several species, as well as Neolithic, Medieval, and modern humans, would suggest a physiological effect rather than the widespread use of similar age-specific culturally influenced diets. Nevertheless, isotopic changes during periods of growth have not been observed in some studies investigating this effect in bone, such as that of Waters-Rist and Katzenberg (2010), but they suggest this may be influenced by the slow rate of growth in long bones, which could mask any temporary dips in $\delta^{15} \mathrm{~N}$ values. The higher temporal resolution expressed by soft tissue and hair analysis is more equipped to show this feature, and it appears to be captured by the incremental data presented in this paper. Supporting this, an incremental dentine study by Henderson et al. (2014) covering ages 0 to 8 also indicated lower $\delta^{15} \mathrm{~N}$ values during childhood, which they relate to growth effects.

As all the individuals analysed for their incremental dentine in this study survived into adulthood and had relatively high $\delta^{15} \mathrm{~N}$ bone values, indicative of higher socioeconomic status, it could be concluded that they had comparatively healthy childhoods and experienced little physiological stress. Therefore, these $\sim 23$-year dietary profiles may provide valuable insight into the early lives of typically unstressed individuals in Medieval Hereford. In this context, the fact that the incremental $\delta^{15} \mathrm{~N}$ and $\delta^{13} \mathrm{C}$ values of all five individuals fluctuate considerably until around age 18 to 20 (Figure 4 and $5 \mathrm{a}-\mathrm{b}$ ), when they approach their bone value, is especially notable. This underlines the need to consider and investigate more closely the possible effects of physiological processes related to growth, especially when comparing differences in bone collagen isotope data between (weaned) children/sub-adults and adult individuals. These effects could have important interpretational consequences for bulk bone analyses. For instance, individuals who did not reach adulthood may be more appropriately compared with their age group peers than adult individuals and the relatively high age resolution in childhood bulk bone data may offer a different kind of opportunity for intra population analyses. Perhaps, dental seriation of presumably healthy individuals, such as the ones analysed in this paper, may be utilised as comparative data to assess whether deceased children within a burial population may have died from acute (e.g. an accident or acute infection) or chronic causes (e.g. long-term illness or prolonged malnutrition). As incremental data from the young lives of long lived, presumably healthy individuals from the burial population could be understood to present a baseline for a relatively unstressed childhood, using them for comparison to childhood bulk bone data may be preferred to comparison with other bulk bone data. Not only 
to individuals of another age group, because of the growth effect discussed above, but also to those who died during childhood, due to the high possibility of stress or malnutrition affecting the age group mean or median stable isotope value in bone collagen.

Figure 5: box and whisker plot of all incremental dentine $\delta^{15} \mathrm{~N}$ and $\delta^{13} \mathrm{C}$ values at calculated approximate age in years, with bone values of children from St. Guthlac's population overlain at the appropriate age range.
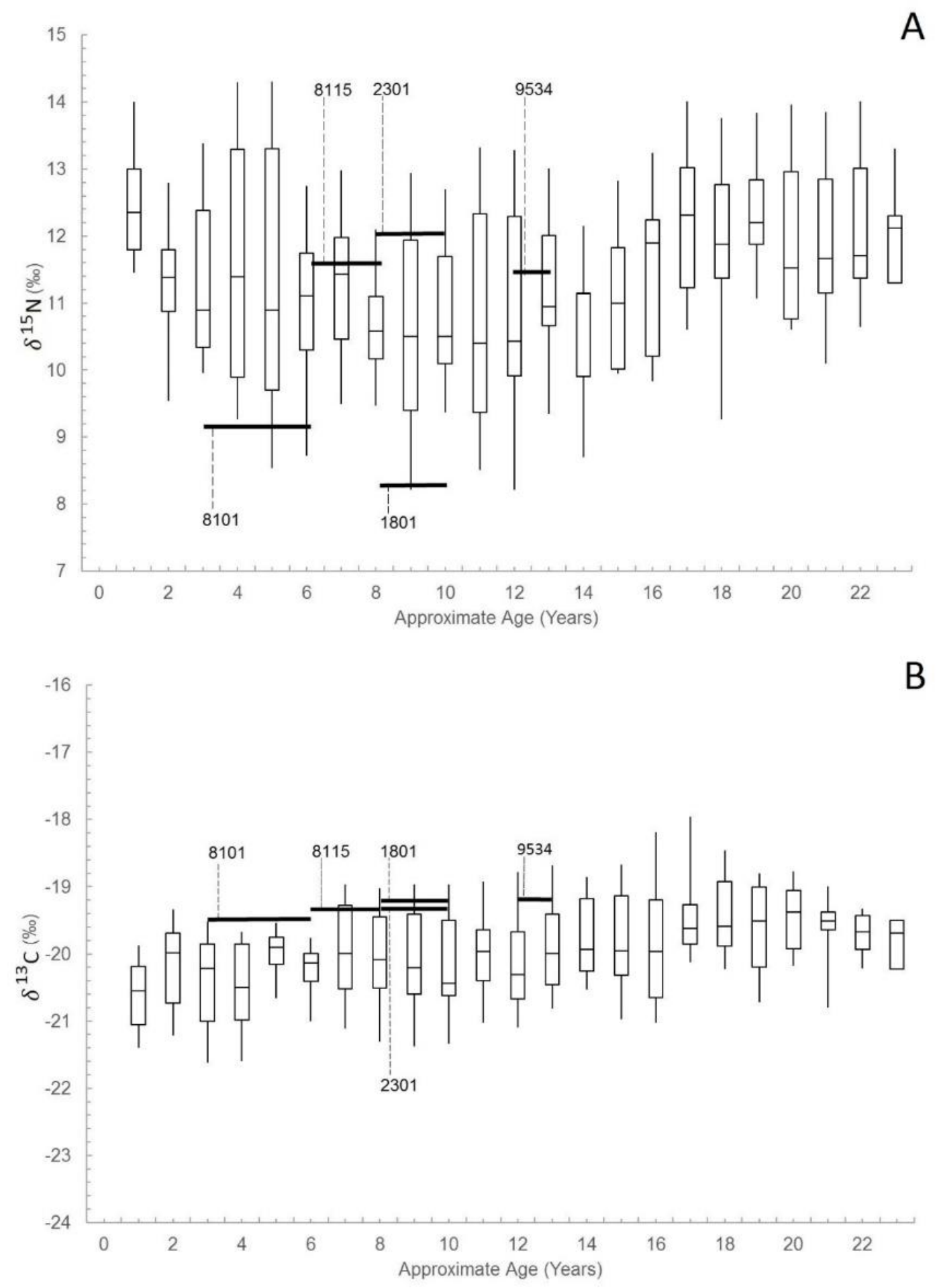
For example, almost all analysed individuals at St. Guthlac's Priory who died during childhood have bone collagen values that fall within the upper and lower quartile ranges expressed by the corresponding age within the incremental dentine samples, for both $\delta^{15} \mathrm{~N}$ and $\delta^{13} \mathrm{C}$ (Figure 5a-b). This suggests that their bone values represent normal, underlying physiological processes rather than poor long-term health or unusual diet, leading to the hypothesis that their death was sudden and not caused by a chronic condition. Conversely, individual 1801 has a $\delta^{15} \mathrm{~N}$ value that lies below the range of the values for the corresponding incremental dentine age, suggesting less access to animal protein throughout their young life compared to their similarly aged peers. In fact, 1801's skeleton was noted as being askew in the grave, implying a hurried burial in the southern part of the burial ground and indicative of a lower socioeconomic status (Crooks, 2005).

\section{Conclusions}

The bone $\delta^{13} \mathrm{C}$ values presented in this paper show that there is little variation in the overall bulk bone values between different burial populations in Hereford, portraying high levels of continuity between Early and Late Medieval populations. Furthermore, there is no statistically significant difference between individuals of varying age or sex. The $\delta^{13} \mathrm{C}$ values are similar to those of other Medieval English populations, suggesting a largely terrestrial diet. In contrast, the Hereford populations carry relatively low $\delta^{15} \mathrm{~N}$ values compared to their Late Medieval counterparts, possibly caused by less access to ${ }^{15} \mathrm{~N}$ enriched protein, but lack of geographic and faunal data in proximity to Hereford means they cannot be accurately compared. The incremental profiles present several similar characteristics, such as lower values during childhood, possibly caused by physiological processes related to growth and development, rather than a specific childhood diet or illness. We suggest that the bone collagen $\delta^{13} \mathrm{C}$ and $\delta^{15} \mathrm{~N}$ values of children and young adults should be considered separately from those of fully developed adults. Furthermore, that the incremental dentine profiles of presumably healthy older adults may be used as intra-population standards with which to compare the bone collagen values of those who died during childhood in order to better identify outliers within that population.

\section{Acknowledgements}

We would like to thank our respective institutions and the Stable Isotope Biochemistry Laboratory, Durham University, for their support. Katy Ulewicz for the work she did on the bone material from St Guthlac's Priory in the course of her MSc dissertation research at Durham University and Kurt Gron for his advice on preparing the manuscript. We are grateful to Kayla Crowder and Joanna Moore for their help and advise with the incremental dentine sampling prep. We would also like to thank Charlotte Roberts and Tina Jakob for granting permission to sample the skeletal remains from St Guthlac's Priory and the Wye valley NHS trust for funding the associated excavation work. 


\section{References}

AIQahtani, S., Hector, M., and Liversidge, H., 2010. Brief communication: the London atlas of human tooth development and eruption. American Journal of Physical Anthropology 142, 481-490.

Ambrose, S.H., 1990. Preparation and characterization of bone and tooth collagen for isotopic analysis. Journal of Archaeological Science 17, 431-451.

Balasse, M. and Ambrose, S.H., 2005. Distinguishing sheep and goats using dental morphology and stable carbon isotopes in C4 grassland environments. Journal of Archaeological Science 32 (5), 691-702.

Beaumont, J., and Montgomery, J., 2015. Oral histories: a simple method of assigning chronological age to isotopic values from human dentine collagen. Annals of Human Biology 42 (4), 407-414.

Beaumont, J., and Montgomery, J., 2016. The Great Irish famine: identifying starvation in the tissues of victims using stable isotope analysis of bone and incremental dentine collagen.

PloS one, 11 (8).

Beaumont, J., Gledhill, A., Lee-Thorp, J. and Montgomery, J., 2013. Childhood Diet: A closer examination of evidence from dental tissues using stable isotope analysis of incremental human dentine, Archaeometry 55 (2), 277-295.

Beaumont, J., Gledhill, A., and Montgomery, J., 2014. Isotope analysis of incremental human

dentine: towards higher temporal resolution. Bulletin of the International Association for Paleodontology 8 (2), 212-223.

Beaumont, J., Montgomery, J., Buckberry, J., and Jay, M., 2015. Infant mortality and isotopic complexity: new approaches to stress, maternal health, and weaning. American Journal of Physical Anthropology 157 (3), 441-457.

Bogaard, A., Heaton, T.H.E., Poulton, P., and Merbach, I., (2007). The impact of manuring on nitrogen isotope ratios in cereals: archaeological implications for reconstruction of diet and crop management practices. Journal of Archaeological Science 34, 335-343.

Boucher, A., Craddock-Bennet, L., and Daly, T., 2015. Death in the Close: A Medieval Mystery. Edinburgh, Headland Archaeology.

Brown, T.A., Nelson, D.E., Vogel, J.S., Southon, J.R., 1988. Improved collagen extraction by modified Longin method. Radiocarbon 30, 171-177.

Burt, N.M., 2015. Individual dietary patterns during childhood: an archaeological application of a stable isotope microsampling method for tooth dentin. Journal of Archaeological Science 53, 277-290.

Cerling, T.E., 1993. Stable carbon and oxygen isotopes in soil carbonates. Geophysical Monograph 78, 217-231.

Cox, G., and Sealy, J., 1997. Investigating identity and life history: isotopic analysis and historical documentation of slave skeletons found in the Cape Town foreshore, South Africa. International Journal of Historical Archaeology 1, 207-224.

Crooks, K., 2005. Excavations at Hereford county hospital. Report SMR 31923.

Archaeological Investigations Ltd.

Curtis-Summers, S., Montgomery, J., and Carver, M., 2014. Stable isotopic evidence for dietary contrast between Pictish and Medieval populations at Portmahomack, Scotland. Medieval Archaeology 58, 21-43.

Dempson, J.B., Braithwaite, V.A., Doherty, D., and Power, M., 2009. Stable isotope analysis of marine feeding signatures of Atlantic salmon in the North Atlantic. ICES Journal of Marine Science 67, 52-61.

DeNiro, M., 1985. Postmortem preservation and alteration in in vivo bone collagen isotope ratios in relation to paleodietary reconstruction. Nature 317, 806-809.

Eerkens, J.W., Sullivan, K., and Greenwald, A.M., 2016. Stable isotope analysis of serial samples of third molars as insight into inter-and intra-individual variation in ancient diet. Journal of Archaeological Science: Reports 5, 656-663. 
Farquhar, G.D., Ehleringer, J.R., and Hubick, K.T., 1989. Carbon isotope discrimination and photosynthesis. Annual Review of Plant Biology, 40 (1), 503-537.

Forrest, I., 2010. The politics of burial in Late Medieval Hereford. English Historical Review, Vol. CXXV 516, 1110-1138.

Fuller, B.T., Fuller, J.L., Sage, N.E., Harris, D.A., O'Connell, T.C., and Hedges, R.E., 2004. Nitrogen balance and $\delta^{15} \mathrm{~N}$ : why you're not what you eat during pregnancy. Rapid Communications in Mass Spectrometry 18 (23), 2889-2896.

Fuller, B.T., Fuller, J.L., Sage, N.E., Harris, D.A., O'Connell, T.C., and Hedges, R.E., 2005. Nitrogen balance and $\delta^{15} \mathrm{~N}$ : why you're not what you eat during nutritional stress. Rapid Communications in Mass Spectrometry 19 (18), 2497-2506.

Fuller, B.T., Fuller, J.L., Harris, D.A., and Hedges, R.E., 2006. Detection of breastfeeding and weaning in modern human infants with carbon and nitrogen stable isotope ratios. American Journal of Physical Anthropology 129, 279-293.

Hedges, R., Clement, J.G., David, C., Thomas, L., and, O'Connell, T., 2007. Collagen turnover in the adult femoral mid-shaft: modeled from anthropogenic radiocarbon tracer measurements. American Journal of Physical Anthropology 133 (2), 808-816.

Henderson, R.C., Lee-Thorp, J.A., and Loe, L., 2014. Early life histories of the London poor using $\delta^{13} \mathrm{C}$ and $\delta^{15} \mathrm{~N}$ stable isotope incremental dentine sampling. American Journal of Physical Anthropology 154 (4), 585-593.

Hurst, D., Baxter, I., Boylston, A., Pearson, E., and Weston, D., 2003. Mappa Mundi Archive, Hereford: assessment and updated project design. Unpublished report. Worcestershire Archaeological Service.

Katzenberg, M.A., Lovell, N.C., 1999. Stable isotope variation in pathological bone. International Journal of Osteoarchaeology 9 (5), 316-324.

Lee-Thorp, J.A., 2008. On isotopes and old bones. Archaeometry 50 (6), 925-950.

McCutchan, J.H., Lewis, W.M., Kendall, C., and McGrath, C.C., 2003. Variation in trophic shift for stable isotope ratios of carbon, nitrogen, and sulfur. Oikos, 102 (2), 378-390.

Longin, R., 1971. New method of collagen extraction for radiocarbon dating: Nature 230, 241-242.

Mekota, A.M., Grupe, G., Ufer, S., and Cuntz, U., 2006. Serial analysis of stable nitrogen and carbon isotopes in hair: monitoring starvation and recovery phases of patients suffering from anorexia nervosa. Rapid Communications in Mass Spectrometry 20 (10), 1604-1610. Minagawa, M., and Wada, E., 1984. Stepwise enrichment of ${ }^{15} \mathrm{~N}$ along food chains: further evidence and the relation between $\delta^{15} \mathrm{~N}$ and animal age. Geochimica et Cosmochimica Acta 48 (5), 1135-1140.

Montgomery, J., Beaumont, J., Jay, M., Keefe, K., Gledhill, A., Cook, G., Dockrill S., and Melton, N., 2013. Strategic and sporadic marine consumption at the onset of the Neolithic: increasing temporal resolution in the isotope evidence. Antiquity 87, 1060-1072.

Müldner, G and Richards, M.P., 2005. Fast or feast: reconstructing diet in later Medieval England by stable isotope analysis. Journal of Archaeological Science 32, 39-48.

Müldner, G. and Richards, M. P., 2006. Diet in Medieval England: the evidence from stable isotopes. In: Woolgar, C., Serjeantson, D. and Waldron, T. (eds.), Food in Medieval England: History and Archaeology. Oxford: Oxford University Press, pp. 228-238.

Müldner, G., and Richards, M.P., 2007a. Stable isotope evidence for 1500 years of human diet at the city of York, UK. American Journal of Physical Anthropology 133, 681-697. Müldner, G., and Richards, M., 2007b. Diet and diversity at Later Medieval Fishergate: the isotopic evidence, American Journal of Physical Anthropology 134, 162-174.

Patrick, P., 2014. The 'Obese Medieval Monk' A multidisciplinary study of a stereotype.

Oxford: Archaeopress BAR British Series, 590.

Pearson, J.A., Haddow, S.D., Hillson, S.W., Knüsel, C.J., Larsen, C.S., and Sadvari, J.W., 2015. Stable carbon and nitrogen isotope analysis and dietary reconstruction through the life course at Neolithic Çatalhöyük, Turkey. Journal of Social Archaeology 15 (2) 210-232.

Price, J., 1796. An Historical Account of the City of Hereford. With some Remarks on the River Wye, and the Natural and Artificial Beauties Contiguous to its Banks, from Brobery to Wilton. Hereford: D. Walker. 
Reitsema, L.J., 2013. Beyond diet reconstruction: stable isotope applications to human physiology, health, and nutrition. American Journal of Human Biology 25(4), 445-456. Reitsema, L.J., and Muir, A.B., 2015. Growth, velocity and weaning $\delta^{15} \mathrm{~N}$ "dips" during ontogeny in Macaca mulatta. American Journal of Physical Anthropology 157 (2), 347-357. Reynard, L., and Tuross, N., 2015. The known, the unknown and the unknowable: weaning times from archaeological bones using nitrogen isotope ratios. Journal of Archaeological Science 53, 618-625.

Richards, M., Mays, S., Fuller, B., 2002. Stable carbon and nitrogen isotope values of bone and teeth reflect weaning age at the Medieval Wharram Percy site, Yorkshire, UK. American Journal of Physical Anthropology 119, 205-210.

Roberts, C., (2005). The human skeletal report. Appendix to Crooks K.H. Excavations at Hereford, County Hospital. Report SMR 31923. Archaeological Investigations Ltd.

Roth, J.D., and Hobson, K.A., 2000. Stable carbon and nitrogen isotopic fractionation between diet and tissue of captive red fox: implications for dietary reconstruction. Canadian Journal of Zoology 78, 848-852.

Sandberg, P.A., Sponheimer, M., Lee-Thorp, J., and van Gerven, D., 2014. Intra-tooth stable isotope analysis of dentine: a step toward addressing selective mortality in the reconstruction of life history in the archaeological record. American Journal of Physical Anthropology 155 (2), 281-293.

Schoeninger, M.J., and DeNiro, M.J., 1984. Nitrogen and carbon isotopic composition of bone collagen from marine and terrestrial animals. Geochimica et Cosmochimica Acta 48, 625-639.

Stott, A.W., Evershed, R.P., Jim, S., Jones, V., Rogers, J.M., Tuross, N., and Ambrose, S., 1999. Cholestrol as a new source of palaeodietary information: experimental approaches and archaeological applications. Journal of Archaeological Science 26 (6), 705-716. Thompson, A.H., Chaix, L., and Richards, M.P, 2008. Stable isotopes and diet at ancient Kerma, Upper Nubia (Sudan). Journal of Archaeological Science 35 (2), 376-387. van der Sluis, L.G., Reimer, P.J., and Lynnerup, N., 2015. Investigating intra-individual dietary changes and ${ }^{14} \mathrm{C}$ ages using high-resolution $\delta^{13} \mathrm{C}$ and $\delta{ }^{15} \mathrm{~N}$ isotope ratios and ${ }^{14} \mathrm{C}$ ages obtained from dentine increments. Radiocarbon 57 (4), 665-677. Trueman, C.N., McGill, R.A., and Guyard P.H., 2005. The effect of growth rate on tissue-diet isotopic spacing in rapidly growing animals. An experimental study with Atlantic salmon (Salmo salar). Rapid Communications in Mass Spectrometry 19 (22), 3239-3247. van Klinken, G.J., 1999. Bone collagen quality indicators for paleodietary and radiocarbon measurements. Journal of Archaeological Science 26 (6), 687-695.

Waters-Rist, A.L, and Katzenberg, M.A., 2010. The effect of growth on stable nitrogen isotope ratios in subadult bone collagen. International Journal of Osteoarchaeology 20 (2), 172-191.

Werner, R. A., and Brand, W.A., 2001. Referencing strategies and techniques in stable isotope ratio analysis. Rapid Communications in Mass Spectrometry 15 (7), 501-519. Wood, J.W., Milner, G.R., Harpending, H.C., Weiss, K.M., Cohen, M.N., Eisenberg, L.E., Hutchinson, D.L., Jankauskas, R., Česnys, G., Katzenberg, M.A., Lukacs, J.R., McGrath, J.W., Roth, E.A., Ubelaker, D.H., and Wilkinson, R.G., 1992. The osteological paradox: problems of inferring prehistoric health from skeletal samples [and comments and reply]. Current Anthropology 33 (4), 343-370.

Woolgar, C.M., Serjeantson, D., and Waldron, T., (2006). Food in Medieval England. Diet and Nutrition. New York: Oxford University Press. 